\title{
Zika Virus Activity of the Leaf and Branch Extracts of Tontelea micrantha and Its Hexane Extracts Phytochemical Study
}

\author{
Fernanda L. Ferreira, ${ }^{a}$ Marcela S. Hauck, ${ }^{b}$ Lucienir P. Duarte, ${ }^{*, a}$ \\ José C. de Magalhães, ${ }^{b}$ Louise S. M. da Silva, ${ }^{a}$ Lúcia P. S. Pimenta, ${ }^{a}$ Julio C. D. Lopes, ${ }^{a}$ \\ Maria O. Mercadante-Simões ${ }^{c}$ and Sidney A. Vieira Filho ${ }^{d}$ \\ ${ }^{a}$ Departamento de Química, Instituto de Ciências Exatas, Universidade Federal de Minas Gerais, \\ 31270-901 Belo Horizonte-MG, Brazil \\ ${ }^{b}$ Departamento de Química, Biotecnologia e Engenharia de Bioprocessos, \\ Universidade Federal de São João del-Rei, Campus Alto Paraopeba, \\ 36420-000 Ouro Branco-MG, Brazil \\ 'Departamento de Biologia Geral, Centro de Ciências Biológicas e da Saúde, \\ Universidade Estadual de Montes Claros, 39401-089 Montes Claros-MG, Brazil \\ ${ }^{d}$ Departamento de Farmácia, Escola de Farmácia, Universidade Federal de Ouro Preto, \\ Campus Morro do Cruzeiro, 35400-000 Ouro Preto-MG, Brazil
}

\begin{abstract}
The new triterpene friedelan-1,3,21-trione, the known compounds friedelan-3-one, $3 \beta$-friedelinol, 3,4-seco-friedelan-3-oic acid, 28-hydroxyfriedelan-3-one, friedelan-3-oxo28-al, friedelan-3,21-dione, 30-hydroxyfriedelan-3-one, a mixture of 30-hydroxyfriedelan3-one/21 $\alpha$-hydroxyfriedelan-3-one, $21 \beta$-hydroxyfriedelan-3-one, gutta-percha, squalene, and a mixture of palmitic/stearic/oleic acids were isolated from the hexane extracts of leaves and branches of T. micrantha. Their chemical structures were established by Fourier transform infrared spectroscopy (FTIR), gas chromatography (GC), 1D/2D nuclear magnetic resonance (NMR) and comparison with the literature data. All compounds were described for T. micrantha and the genus Tontelea for the first time. The branch and leaf extracts displayed anti-Zika virus activity at the lowest tested concentration of $15.6 \mu \mathrm{g} \mathrm{mL}^{-1}$, mainly virucidal effect, and presented no cytotoxicity to Vero cells. Furthermore, the ethyl acetate and methanolic leaf extracts demonstrated the best activities at the concentration of 31.2 and $15.6 \mu \mathrm{g} \mathrm{mL} \mathrm{m}^{-1}$ at the viral adsorption and penetration stages, respectively. These results showed that these extracts may be promising candidates for the Zika virus treatment.
\end{abstract}

Keywords: Tontelea micrantha, Celastraceae, friedelan-1,3,21-trione, antiviral activity, Zika virus

\section{Introduction}

The Celastraceae family comprises about 106 genera with 1300 species. ${ }^{1,2}$ Many Brazilian species of this family have been studied due to their use in traditional medicine and pharmacological properties. ${ }^{2}$ Tontelea micrantha (Mart.) A.C.Sm. is a species of the Celastraceae family popularly known as "rufão" and is found in the Brazilian Cerrado, mainly in the north of Minas Gerais State. The alcoholic extracts of its roots are used in the traditional medicine for the treatment of kidney disturbs, and the

*e-mail: lucienir@ufmg.br fruit oils are employed to treat inflammatory processes. ${ }^{3-5}$ Furthermore, its fruits are edible, suggesting low or even absent toxicity. Even though the literature ${ }^{3}$ also describes the histochemical and pharmacognostic profile of the aerial and underground parts of T. micrantha, there are no reports of detailed chemical studies of this species or some other member of the Tontelea genus.

Phytochemical studies of the Celastraceae family led to the isolation of many bioactive secondary metabolites such as flavonoids, steroids and different classes of pentacyclic triterpenes. Also, many reports describe pharmacological properties of triterpenes like anti-inflammatory, ${ }^{6,7}$ antiulcerogenic, ${ }^{8}$ analgesic, ${ }^{9}$ antibacterial, antifungal, 
antiviral, antiparasitic, antioxidant, hepatoprotective, neuroprotective, insecticidal and others. ${ }^{10}$ Moreover, some species are already employed in the treatments of gastric ulcers, presenting anti-inflammatory and analgesic activities such as Maytenus ilicifolia Mart. ex Reiss. and M. aquifolium Reiss. ${ }^{11}$ Additionally, the hydroalcoholic leaf extract from $M$. ilicifolia was active against bovine herpesvirus type 5 and avian metapneumovirus. ${ }^{12}$

Viral infections represent an important target to the pharmacological research, especially aiming virus such as the Zika virus (ZIKV). Infections by ZIKV can be very serious and dangerous for pregnant women because it may induce microcephaly, a brain anomaly that causes a malformation of the brain and head of newborns, loss of pregnancy, stillbirth and other congenital disabilities. ${ }^{13,14}$ In the years 2015-2016, an outbreak in Brazil occurred causing a 10-fold increase in newborns with microcephaly in comparison with previous years. ${ }^{13-15}$ Unfortunately, there is no treatment or specific drugs against ZIKV until this moment. For these reasons, researches leading to potential

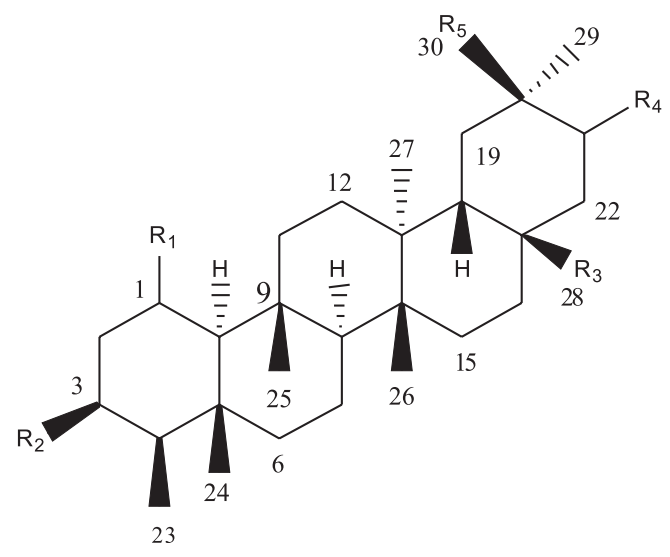

antiviral substances are essential. ${ }^{16,17}$ In this context, the Celastraceae family represents a source of high diversity for bioprospecting new substances with antiviral properties.

In the present work, the effect of leaf and branch extracts of T. micrantha against ZIKV was evaluated. Furthermore, the phytochemical study of the hexane extract of leaves and branches led to the identification of fourteen known compounds and the novel triterpene friedelan1,3,21-trione (Figure 1), herein described for the first time. All compounds were characterized using spectroscopic analysis and comparison with the literature data.

\section{Experimental}

\section{General procedures}

Silica gel G-60 (0.25 mm, Merck) plates were used for thin layer chromatography (TLC), and silica gel $60(0.063-0.200 \mathrm{~mm}$, Merck) or silica flash (0.040-0.063 mm, Sigma-Aldrich) were employed for

\begin{tabular}{cccccc}
\hline Compound & $\mathrm{R}_{1}$ & $\mathrm{R}_{2}$ & $\mathrm{R}_{3}$ & $\mathrm{R}_{4}$ & $\mathrm{R}_{5}$ \\
\hline $\mathbf{1}$ & $\mathrm{O}$ & $=\mathrm{O}$ & $\mathrm{CH}_{3}$ & $=\mathrm{O}$ & $\mathrm{CH}_{3}$ \\
$\mathbf{2}$ & $\mathrm{H}$ & $=\mathrm{O}$ & $\mathrm{CH}_{3}$ & $\mathrm{H}$ & $\mathrm{CH}_{3}$ \\
$\mathbf{3}$ & $\mathrm{H}$ & $\mathrm{OH}$ & $\mathrm{CH}_{3}$ & $\mathrm{H}$ & $\mathrm{CH}_{3}$ \\
$\mathbf{5}$ & $\mathrm{H}$ & $=\mathrm{O}$ & $\mathrm{CH}_{2} \mathrm{OH}$ & $\mathrm{H}$ & $\mathrm{CH}_{3}$ \\
$\mathbf{6}$ & $\mathrm{H}$ & $=\mathrm{O}$ & $\mathrm{CHO}$ & $\mathrm{H}$ & $\mathrm{CH}_{3}$ \\
7 & $\mathrm{H}$ & $=\mathrm{O}$ & $\mathrm{CH}_{3}$ & $=\mathrm{O}$ & $\mathrm{CH}_{3}$ \\
$\mathbf{8}$ & $\mathrm{H}$ & $=\mathrm{O}$ & $\mathrm{CH}_{3}$ & $\mathrm{H}$ & $\mathrm{CH}_{2} \mathrm{OH}$ \\
9 & $\mathrm{H}$ & $=\mathrm{O}$ & $\mathrm{CH}_{3}$ & $\alpha \mathrm{OH}$ & $\mathrm{CH}_{3}$ \\
10 & $\mathrm{H}$ & $=\mathrm{O}$ & $\mathrm{CH}_{3}$ & $\beta \mathrm{OH}$ & $\mathrm{CH}_{3}$ \\
\hline
\end{tabular}

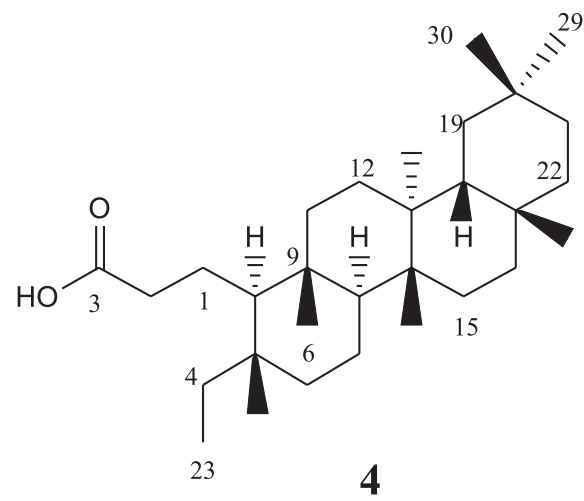

4

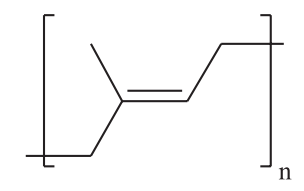

11

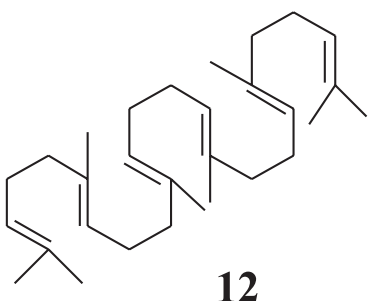

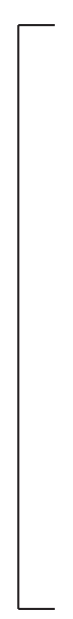

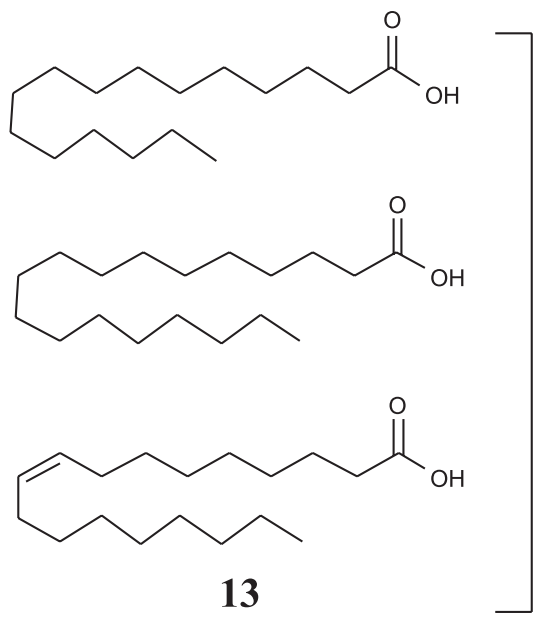

Figure 1. Chemical structures of compounds from hexane leaf and branch extracts of Tontelea micrantha. 
column chromatography (CC). Hexane (Hex, Vetec), chloroform $\left(\mathrm{CHCl}_{3}\right.$, Vetec), ethyl acetate (EtOAc, Vetec) and methanol $(\mathrm{MeOH}, \mathrm{Vetec})$, pure or in gradient mixtures, were used as eluents. The ${ }^{1} \mathrm{H}(400 \mathrm{MHz})$ and ${ }^{13} \mathrm{C}(100 \mathrm{MHz})$ nuclear magnetic resonance (NMR) spectra were performed on a Bruker Avance DRX-400, operating at $300 \mathrm{~K}$. The chemical shift assignments $(\delta)$ and the coupling constants $(J)$ were expressed in ppm and $\mathrm{Hz}$, respectively, using tetramethylsilane (TMS) as reference $\left(\delta_{\mathrm{H}}=\delta_{\mathrm{C}}=0\right)$. The samples were dissolved in $\mathrm{CDCl}_{3}$ pure or with drops of Py- $\mathrm{D}_{5}$. The infrared (IR) spectra $\left(\mathrm{KBr}, \mathrm{cm}^{-1}\right)$ were obtained on a Shimadzu IR408 spectrometer. The melting points were determined using an MQAPF-302 (Microquímica Equipamentos Ltda.) apparatus. The optical rotation was measured on an ADP220 Bellinghan + Stanley Ltd. polarimeter. Liquid chromatography mass spectrometry (LC-MS) analysis was performed on a Bruker Daltonics (MicroTOF QII model) equipped with a high resolution electrospray ionization source and a time of flight analyzer (HR-ESI-TOF), operating in the positive ion mode. The gas chromatography (GC) analyses were performed on HP7820A (Agilent) system equipped with flame ionization detector (FID) and Supelcowax-10 column $(15 \mathrm{~m} \times 0.2 \mathrm{~mm} \times 0.2 \mu \mathrm{m})($ Supelco). The following analytical conditions were used: $1.0 \mu \mathrm{L}$ of injected sample solution, column temperature at $120^{\circ} \mathrm{C}(1 \mathrm{~min})$ up to $240{ }^{\circ} \mathrm{C}\left(10^{\circ} \mathrm{C} \mathrm{min}^{-1}\right)$, injector at $250^{\circ} \mathrm{C}$, split $1: 50$, detector at $260{ }^{\circ} \mathrm{C}$ and $\mathrm{H}_{2}\left(3.0 \mathrm{~mL} \mathrm{~min}^{-1}\right)$ as the carrier gas. Data acquisition was carried out using EZChrom Elite Compact Software 3.3.2 (Agilent). The sample $(5.0 \mathrm{mg}$ ) was heated with $100 \mu \mathrm{L}$ of $14 \% \mathrm{BF}_{3}$-methanol solution in a water bath $\left(60^{\circ} \mathrm{C}\right.$ for $10 \mathrm{~min}$ ), and the fatty acid methyl esters (FAME) were further extracted with hexane. This hexane solution was analyzed by GC-FID, and the observed retention times were compared with reference standards FAME (Supelco: 47885-U).

\section{Plant material}

Leaves and branches of T. micrantha were collected in Montes Claros, Minas Gerais State, Brazil. The plant was identified by the botanist Dr Maria Olívia MercadanteSimões and a voucher specimen (No. BHCB 144.623) was deposited in the Herbarium of Departamento de Botânica, Instituto de Ciências Biológicas, Universidade Federal de Minas Gerais, Brazil.

\section{Extraction and isolation}

After dried at room temperature, samples of leaves and branches of T. micrantha were fragmented in a knife mill resulting in powders (720.0 g for leaves; $2.6 \mathrm{~kg}$ for branches) that were macerated with organic solvents further removed using a rotatory evaporator. The following extracts were obtained for the leaves: hexane ( $43.5 \mathrm{~g})$, ethyl acetate (ELE, $45.0 \mathrm{~g}$ ), and methanolic (MLE, $38.3 \mathrm{~g}$ ). The following extracts were obtained for the branches: hexane (25.7 g), chloroform (CBE, $61.1 \mathrm{~g}$ ) and ethyl acetate (EBE, $9.75 \mathrm{~g}$ ). During the hexane removal, white solids precipitated from both extracts and were separated by filtration (WLS, $0.87 \mathrm{~g}$ from leaves, and WBS, $5.3 \mathrm{~g}$ from branches). These solids were further chromatographed.

TLC analysis of the hexane extracts from leaves and branches showed that both have an expressive amount of the polymer trans-1,4-polyisoprene (gutta-percha), which is very common in the Celastraceae family. ${ }^{18}$ Rodrigues et al..$^{19}$ described an efficient method for guttapercha removal from the extract, which consists in a silica gel CC exhaustively eluted with methanol followed by chloroform. The first elution using $\mathrm{MeOH}$ removes all compounds except gutta-percha that remains retained at the top of the column. Then, this polymer is isolated by eluting the column with chloroform.

Employing the methodology described by Rodrigues et al. ${ }^{19}$ the hexane extracts from the leaves $(43.5 \mathrm{~g})$ and branches $(25.7 \mathrm{~g})$ were chromatographed on silica gel CC, firstly with $\mathrm{MeOH}$ until the TLC analysis showed no more eluted compounds, and then with $\mathrm{CHCl}_{3}$. The chloroform fractions from leaves and branches furnished gutta-percha (11) (20.3 and $1.5 \mathrm{~g}$, respectively). The methanolic fraction from the leaves, after solvent removal with a rotatory evaporator, yielded $15.0 \mathrm{~g}$ of a greenish solid (HLE). Differently, the initial methanolic fraction from the branches presented a yellow color and it was reduced with a rotatory evaporator furnishing $2.2 \mathrm{~g}$ of a yellowish solid (YBS). Continuing the elution with $\mathrm{MeOH}$, a further fraction was then separated until the TLC analysis showed no more eluted compounds, leading to a slightly greenish solid (HBE, $20.4 \mathrm{~g}$ ) after solvent removal. All solids were further chromatographed.

The solid from the hexane leaf extract (WLS, $0.87 \mathrm{~g}$ ) was subjected to silica gel CC (A) furnishing 101 fractions of $20 \mathrm{~mL}$. The fractions A32-37 (Hex: $\mathrm{CHCl}_{3}$ 65:35) yielded friedelan-3-one (2) $(62.7 \mathrm{mg})$ and the fractions A39-48 (Hex: $\mathrm{CHCl}_{3}$ 7:3) provided a mixture of compounds $\mathbf{2}$ and 3ß-friedelinol (3) (324.0 mg).

The solid from the hexane branch extract (WBS, $5.3 \mathrm{~g})$ was fractionated on silica gel CC (B) leading to 321 fractions of $15 \mathrm{~mL}$. An additional amount of 2 $(28.0 \mathrm{mg}$ ) was isolated from the fractions B136-153 $\left(\mathrm{CHCl}_{3}\right)$. Friedelan-3-oxo-28-al (6) $(62.6 \mathrm{mg})$ was obtained from the fractions B167-180 $\left(\mathrm{CHCl}_{3}\right.$ :EtOAc 85:15). 
The fractions B181-189 $\left(\mathrm{CHCl}_{3}:\right.$ EtOAc 8:2) yielded friedelan-3,21-dione (7) (2.2 g). The fractions B190-197 $\left(\mathrm{CHCl}_{3}:\right.$ EtOAc 75:25, $\left.0.96 \mathrm{~g}\right)$ were re-chromatographed on silica gel CC (C) and 111 fractions of the $10 \mathrm{~mL}$ were obtained. The fractions $\mathrm{C} 33-34\left(\mathrm{CHCl}_{3}\right.$ :EtOAc 9:1) furnished additional amount of $7(18.0 \mathrm{mg})$. The fractions C35-43 $\left(\mathrm{CHCl}_{3}:\right.$ EtOAc 85:15, $\left.0.77 \mathrm{~g}\right)$ were submitted to a new $\mathrm{CC}(\mathrm{D}, 78$ fractions of the $15 \mathrm{~mL}$ ) yielding 7 $(5.2 \mathrm{mg})$ from the fraction $\mathrm{D} 43\left(\mathrm{CHCl}_{3}:\right.$ EtOAc $\left.98: 2\right)$ and friedelan-1,3,21-trione (1) $(535.0 \mathrm{mg})$ from the fractions D45-50 $\left(\mathrm{CHCl}_{3}\right.$ :EtOAc 85:15). The fractions B198-245 $\left(\mathrm{CHCl}_{3}:\right.$ EtOAc 80:20, $\left.1.17 \mathrm{~g}\right)$ were re-chromatographed on silica gel CC (E, 81 fractions of the $15 \mathrm{~mL}$ ) providing a mixture $(467.6 \mathrm{mg}$ ) of 30-hydroxyfriedelan-3-one (8) and $21 \alpha$-hydroxyfriedelan-3-one (9) from the fractions E40-44 $\left(\mathrm{CHCl}_{3}:\right.$ EtOAc 85:15). This mixture was purified on flash silica CC (F, 107 fractions of the $10 \mathrm{~mL}$ ) yielding 8 $(165.0 \mathrm{mg})$ from the fractions F64-67 $\left(\mathrm{CHCl}_{3}:\right.$ EtOAc 90:10).

Part of the greenish solid from hexane leaf extract free of gutta (HLE) (14.0 g) was chromatographed on silica gel CC (G) furnishing 102 fractions of $200 \mathrm{~mL}$. The fractions G1-6 (Hex) yielded squalene (12) (410.0 mg). The fractions G30-38 ( $\mathrm{Hex}: \mathrm{CHCl}_{3}$ 8:2, $3.6 \mathrm{~g}$ ) were subjected to a new silica gel $\mathrm{CC}(\mathrm{H})$ providing 88 fractions of $30 \mathrm{~mL}$. The fractions H56-58 (Hex: $\mathrm{CHCl}_{3}$ 9:1) afforded $2(45.0 \mathrm{mg})$ and the fractions $\mathrm{H} 79-87\left(\mathrm{CHCl}_{3}\right)$ yielded 3,4-seco-friedelan-3-oic acid (4) (73.0 mg). The fractions H63-78 ( $\mathrm{Hex}_{\mathrm{CHCl}} \mathrm{CH}_{3}$ 1, $2.04 \mathrm{~g}$ ) were re-submitted to a new silica gel CC (I) providing 186 fractions of $20 \mathrm{~mL}$. Additional amounts of $\mathbf{2}(12.0 \mathrm{mg})$ and $\mathbf{3}(85.8 \mathrm{mg})$ were isolated from the fractions $153-55\left(\mathrm{Hex}: \mathrm{CHCl}_{3} 65: 35\right)$ and I57-74 ( $\mathrm{Hex}: \mathrm{CHCl}_{3}$ 65:35), respectively. The fractions G39-45 (Hex: $\mathrm{CHCl}_{3} 8: 2,3.55 \mathrm{~g}$ ) were re-chromatographed on flash silica CC (J, 100 fractions of $30 \mathrm{~mL})$, providing 28-hydroxyfriedelan-3-one $(5)(22.5 \mathrm{mg})$ from the fractions J46-67 (Hex: $\mathrm{CHCl}_{3} 85: 15$ ). The fractions J68-84 (Hex: $\mathrm{CHCl}_{3} 1: 1,113.3 \mathrm{mg}$ ) were re-submitted to a new flash silica gel CC (K), furnishing 77 fractions of $10 \mathrm{~mL}$. The mixture of long chain fatty acid (13) $(45.3 \mathrm{mg})$ was isolated from the fractions $\mathrm{K} 53-55\left(\mathrm{CHCl}_{3}:\right.$ EtOAc 8:2). The fractions G46-66 $\left(\mathrm{CHCl}_{3} 7: 3,0.73 \mathrm{~g}\right)$ were re-submitted to a new flash silica $\mathrm{CC}(\mathrm{L})$ providing 37 fractions of $25 \mathrm{~mL}$. The fractions L13-18 (Hex: $\mathrm{CHCl}_{3}$ 8:2) yielded an additional amount of $\mathbf{5}(263.0 \mathrm{mg})$.

Part of the yellowish solid from the hexane branch extract (YBS, $1.8 \mathrm{~g}$ ) after gutta removal was chromatographed on silica gel CC (M) resulting in 212 fractions of $30 \mathrm{~mL}$. The fractions M123-125 $\left(\mathrm{CHCl}_{3}\right.$ :EtOAc 9:1, $\left.0.40 \mathrm{~g}\right)$ were re-chromatographed on flash silica $\mathrm{CC}(\mathrm{N})$ leading to 33 fractions of $10 \mathrm{~mL}$. The fractions $\mathrm{N} 19-29\left(\mathrm{CHCl}_{3}: \mathrm{EtOAc}\right.$
7:3) were identified as 7 (283.2 mg). The fraction M129-130 $\left(\mathrm{CHCl}_{3}\right.$ :EtOAc 8:2) yielded $21 \beta$-hydroxyfriedelan-3-one (10) $(77.0 \mathrm{mg})$. The fractions M131-137 $\left(\mathrm{CHCl}_{3}:\right.$ EtOAc $8: 2,0.14 \mathrm{~g})$ were re-submitted to a new flash silica $\mathrm{CC}(\mathrm{O})$ leading to 59 fractions of $10 \mathrm{~mL}$, furnishing a mixture $(66.6 \mathrm{mg}$ ) of $\mathbf{8}$ and $\mathbf{9}$ from the fractions O34-41 $\left(\mathrm{CHCl}_{3}\right.$ :EtOAc 8:2).

Part of the slightly greenish solid from hexane branch extract free of gutta (HBE, $14.2 \mathrm{~g}$ ) was submitted to silica gel CC (P) furnishing 65 fractions of $250 \mathrm{~mL}$. The fractions P31-32 (Hex: $\mathrm{CHCl}_{3}$ 1:1, $5.33 \mathrm{~g}$ ) were re-chromatographed on silica gel CC $(\mathrm{Q})$ providing 90 fractions of $30 \mathrm{~mL}$. The fractions Q52-59 (Hex:EtOAc 4:6, $1.20 \mathrm{~g}$ ) were re-submitted to a new silica gel CC (R, 157 fractions of $10 \mathrm{~mL})$ and only the fractions R119-129 $\left(\mathrm{CHCl}_{3}: \mathrm{EtOAc}\right.$ 6:4) yielded a pure compound, identified as $7(598.8 \mathrm{mg})$. The fractions Q60-84 (Hex:EtOAc 1:9, $1.08 \mathrm{~g}$ ) were re-subjected to a new silica gel CC (S, 75 fractions of $10 \mathrm{~mL}$ ) providing a mixture of $\mathbf{2}$ and $\mathbf{3}(325.3 \mathrm{mg})$ from the fractions $\mathrm{S} 46-47\left(\mathrm{CHCl}_{3}: \mathrm{EtOAc} 7: 3\right)$. The fractions $\mathrm{S} 48-52$ $\left(\mathrm{CHCl}_{3}:\right.$ EtOAc 6:4, $\left.450.0 \mathrm{mg}\right)$ were re-submitted to a new silica gel CC (T, 78 fractions of $10 \mathrm{~mL}$ ) providing a mixture of 8 and $9(260.5 \mathrm{mg})$ (fractions $\mathrm{T} 26-30, \mathrm{CHCl}_{3}: \mathrm{EtOAc}$ 95:5) and the pure compound $8(85.3 \mathrm{mg}$ ) (fractions T38-46, $\mathrm{CHCl}_{3}:$ EtOAc 92:8). The fractions P33-39 ( $\mathrm{Hex}: \mathrm{CHCl}_{3}$ $8: 2,2.35 \mathrm{~g}$ ) were re-chromatographed on a new silica gel $\mathrm{CC}$ (U, 184 fractions of $15 \mathrm{~mL})$. The fractions U105-114 $\left(\mathrm{CHCl}_{3}:\right.$ EtOAc 4:6, $\left.0.61 \mathrm{~g}\right)$ were submitted to another silica gel CC (V, 96 fractions of $10 \mathrm{~mL})$ yielding additional amounts of 8 and 9 in a mixture $(422.5 \mathrm{mg}$ ) from the fractions V29-35 $\left(\mathrm{CHCl}_{3}\right.$ :EtOAc 9:1).

\section{Cytotoxicity assay}

Prior to the antiviral assays, the $50 \%$ cytotoxic concentration $\left(\mathrm{CC}_{50}\right)$ of the crude extracts of T. micrantha was established for the Vero cell lineage (ATCC CCL-81 ${ }^{\mathrm{TM}}$ ). Vero cells were distributed into 96-wells microplates $\left(4 \times 10^{5}\right.$ cells per $100 \mu \mathrm{L}$ per well $)$ and incubated at $37^{\circ} \mathrm{C}$ for $24 \mathrm{~h}$. Then, $200 \mu \mathrm{L}$ well ${ }^{-1}$ of DMEM (Dulbecco's minimum essential medium) with 5\% FBS (fetal bovine serum, $\mathrm{v} \mathrm{v}^{-1}$ ) and the stock solution of the extracts dissolved in DMSO 20\% in water (final DMSO concentration per well of $0.2 \%$ ) were added starting with $1000 \mu \mathrm{g} \mathrm{mL}^{-1}$ in successive serial dilutions to $7.8 \mu \mathrm{g} \mathrm{mL}{ }^{-1}$. The employed solvent was used as a control (DMSO $0.2 \%$ ), and the assays were performed in triplicate. After the $48 \mathrm{~h}$ incubation period, $25 \mu \mathrm{L}$ of 3-(4,5-dimethyl-2-thiazolyl)-2,5-diphenyl$2 \mathrm{H}$-tetrazolium bromide (MTT) solution $\left(2 \mathrm{mg} \mathrm{mL}^{-1}\right.$ in PBS) was added, and the plates were incubated at $37^{\circ} \mathrm{C}$ for $90 \mathrm{~min}$. Then, $130 \mu \mathrm{L}$ of the solvent (DMSO) was added to 
each well to dissolve the MTT-formazan crystals, and the cultures were kept under stirring at $150 \mathrm{rpm}$ for $15 \mathrm{~min}$. The $\mathrm{CC}_{50}$ was calculated using the absorbance $(\lambda=492 \mathrm{~nm})$ in the wells, determined on a plate reader, as $\mathrm{B} / \mathrm{A} \times 100$ $(\mathrm{A}=$ untreated cells; $\mathrm{B}=$ treated cells $)$. The data presented are the means obtained from at least three experiments with internal triplicates.

\section{Antiviral evaluation}

Only $T$. micrantha extracts that presented a $\mathrm{CC}_{50}$ higher than $100 \mu \mathrm{g} \mathrm{mL} \mathrm{m}^{-1}$ were subjected to in vitro antiviral assays. Vero cells were distributed in a 96-wells microplate $\left(4 \times 10^{5}\right.$ cells per $100 \mu \mathrm{L}$ per well $)$ and incubated at $37^{\circ} \mathrm{C}$ for $24 \mathrm{~h}$. Then, the culture medium was removed, and $100 \mu \mathrm{L}$ serial extract dilutions ( 250 to $15.6 \mu \mathrm{g} \mathrm{mL}^{-1}$ ) were added to the wells. In a second 96-wells microplate, the same serial extract dilutions were mixed with the virus inoculums with a multiplicity of infection (moi), which corresponds to the average number of virus particles infecting each cell, of 0.1 virus cell ${ }^{-1}$. Both 96 -wells microplates were incubated at $5 \% \mathrm{CO}_{2}$ atmosphere at $37{ }^{\circ} \mathrm{C}$ for $30 \mathrm{~min}$. Then, the suspension of the second microplate was transferred to the first microplate containing cells and incubated for $48 \mathrm{~h}$ at $37^{\circ} \mathrm{C}$. This procedure was done to ensure an adequate evaluation of the antiviral effect, investigating the extracts action in the virus and the cells to be infected throughout the multiplicative cycle of the virus. After $48 \mathrm{~h}$ of infection, the methodology for the cytotoxicity assay was used again to establish the median antiviral effective concentration $\left(\mathrm{EC}_{50}\right)$, which is the concentration that induced $50 \%$ protection of treated cells from viral infection. The $\mathrm{EC}_{50}$ was calculated using the absorbance $(\lambda=492 \mathrm{~nm})$ in the wells, determined on a plate reader, as $[(\mathrm{A}-\mathrm{B}) /(\mathrm{C}-\mathrm{B})] \times 100(\mathrm{~A}=$ treated and infected cells; $\mathrm{B}=$ untreated and infected cells; $\mathrm{C}=$ untreated and noninfected cells). The data presented are the means obtained from three experiments with internal triplicates.

\section{Evaluation of the different stages in the viral infection cycle}

In order to establish the antiviral effect, the cells and virus were incubated with active extracts at different stages of the viral infection cycle. At the adsorption stage, the cells were pretreated with the extracts before viral infection. At the penetration stage, the cells were infected with the virus before the addition of the extracts. The virucidal effect was also evaluated to verify if the extracts were capable of interacting with the virus at a stage prior to the viral infection of host cells. Then, the virus was incubated with the extracts before infecting the cells. The data presented are the means obtained from three experiments with internal triplicates.

\section{Antiviral activity at the adsorption stage}

The extracts in concentration ranging from 250.0 to $15.6 \mu \mathrm{g} \mathrm{mL}^{-1}$ (serial dilutions) were added to a monolayer cell (24-wells microplate, $5 \times 10^{5}$ cells well $^{-1}$ ) and maintained at $37^{\circ} \mathrm{C}$ for $1 \mathrm{~h}$ in $5 \% \mathrm{CO}_{2}$ atmosphere. Then, the cells were washed and infected with ZIKV (moi $=0.1$ virus cell ${ }^{-1}$ ). After one hour of viral adsorption, the non-adsorbed viral inoculum was removed and the cells were washed with PBS before addition of $1 \mathrm{~mL}$ of semi-solid medium 199 containing 2\% FBS, 2\% CMC (carboxymethylcellulose, $\mathrm{m} \mathrm{v}^{-1}$ ). After $48 \mathrm{~h}$, the cells were fixed with PBS/10\% formaldehyde $\left(\mathrm{v} \mathrm{v}^{-1}\right)$ for $30 \mathrm{~min}$, washed and stained with $5 \%$ crystal violet solution $\left(\mathrm{m} \mathrm{v}^{-1}\right)$ for $15 \mathrm{~min}$. The viral lysis plaques were observed and compared with untreated and non-infected cells (cell control), cells treated with DMSO $0.2 \%$ and infected (vehicle control), cells treated with ribavirin $200 \mu \mathrm{g} \mathrm{mL}^{-1}$ and infected (drug control) and only infected cells (ZIKV control). Ribavirin (Sigma-Aldrich) was used as a negative control since it can inhibit the viral multiplication in the intracellular phase, but does not prevent viral adsorption.

\section{Antiviral activity at the penetration stage}

Vero cells were distributed in 24-wells microplates $\left(5 \times 10^{5}\right.$ cells per $100 \mu \mathrm{L}$ per well $) 24 \mathrm{~h}$ before the assay, then the cells were infected with ZIKV (moi $=0.1$ virus cell-1 $\left.{ }^{-1}\right)$ without pretreatment and incubated at $4{ }^{\circ} \mathrm{C}$ for one hour. Then, the viral inoculum was removed and the cells were washed with PBS. The extracts in concentration ranging from 250.0 to $15.6 \mu \mathrm{g} \mathrm{mL}^{-1}$ (serial dilutions) were added to the infected cells and maintained at $37^{\circ} \mathrm{C}$ for one hour in $5 \% \mathrm{CO}_{2}$ atmosphere. The extracts were removed, and the cells were washed with citrate buffer $(\mathrm{pH} 3)$ for $1 \mathrm{~min}$. After, a semi-solid medium 199 containing 2\% FBS, 2\% $\mathrm{CMC}\left(\mathrm{m} \mathrm{v}^{-1}\right)$ and the antibiotic mixture were added to the plate, which was incubated at $37{ }^{\circ} \mathrm{C}$ for $48 \mathrm{~h}$ in $5 \%$ $\mathrm{CO}_{2}$ atmosphere. The revelation methodology and control groups were the same as described for the adsorption assays.

\section{Virucidal effect}

The extracts were added to the viral inoculum at $37^{\circ} \mathrm{C}$ for $1 \mathrm{~h}$ before cell infection. Then, they were placed in a 24-wells microplate containing Vero cells and incubated at $37^{\circ} \mathrm{C}$ for $1 \mathrm{~h}$ in $5 \% \mathrm{CO}_{2}$. In the sequence, the viral inoculum 
was removed, a semi-solid medium 199 containing $2 \%$ FBS and $2 \% \mathrm{CMC}\left(\mathrm{m} \mathrm{v}^{-1}\right)$ was added and the microplate was maintained at $37{ }^{\circ} \mathrm{C}$ for $48 \mathrm{~h}$ in $5 \% \mathrm{CO}_{2}$ atmosphere. For the visualization of viral plaques, the cells were treated $48 \mathrm{~h}$ later by fixation with PBS/10\% formaldehyde $\left(\mathrm{v} \mathrm{v}^{-1}\right)$ and stained with $1 \%$ crystal violet solution $\left(\mathrm{m} \mathrm{v}^{-1}\right)$ for $15 \mathrm{~min}$. The control groups were the same as described for the adsorption assays.

\section{Results and Discussion}

\section{Chemistry}

The phytochemical study of hexane leaf and branch extracts of T. micrantha yielded ten friedelane triterpenes (1 to $\mathbf{1 0})$, the natural polymer gutta-percha (11), squalene (12), and a mixture of long-chain fatty acids (13) (Figure 1). All compounds are herein described for the first time as constituents of $T$. micrantha, as well as of the genus Tontelea. The chemical structures of these compounds were characterized by IR, GC, ${ }^{1} \mathrm{H}$ and ${ }^{13} \mathrm{C} \mathrm{NMR}$ and through comparison with literature data.

The triterpene $\mathbf{1}$ was isolated as a white amorphous solid material with $[\alpha]_{\mathrm{D}}^{21}+86.0\left(\mathrm{CHCl}_{3}\right)$ and $\mathrm{mp}$ 224-226 ${ }^{\circ} \mathrm{C}$. Its molecular formula, $\mathrm{C}_{30} \mathrm{H}_{46} \mathrm{O}_{3}$, was established by HR-ESI-MS $\left(\mathrm{m} / \mathrm{z}: 477.3221[\mathrm{M}+\mathrm{Na}]^{+}\right.$, calcd. 477.3339). The IR spectrum showed a large band at $1716 \mathrm{~cm}^{-1}$, which was attributed to carbonyl groups. In this spectrum, the bands at 3548 and $3412 \mathrm{~cm}^{-1}$ were attributed to hydroxyl groups, probably due to the keto-enolic equilibrium. The ${ }^{1} \mathrm{H}$ NMR spectrum showed signals at $\delta_{\mathrm{H}}$ $0.71,1.05,1.07,1.09,1.14,1.16,1.18$ and 1.22 , associated to eight methyl groups. Signals at $\delta_{\mathrm{H}} 2.39(1 \mathrm{H}, \mathrm{s})$, 2.58-2.61 (2H, m), $3.24(1 \mathrm{H}, \mathrm{d}, J 16.0 \mathrm{~Hz})$ and 3.44 $(1 \mathrm{H}, \mathrm{d}, J 16.0 \mathrm{~Hz}$ ) were correlated as $\alpha$-carbonyl protons according to heteronuclear multiple bond correlation (HMBC) and heteronuclear single quantum correlation (HSQC) analyses. The ${ }^{13} \mathrm{C}$ NMR spectrum presented 30 signals that, with the aid of the distortionless enhancement

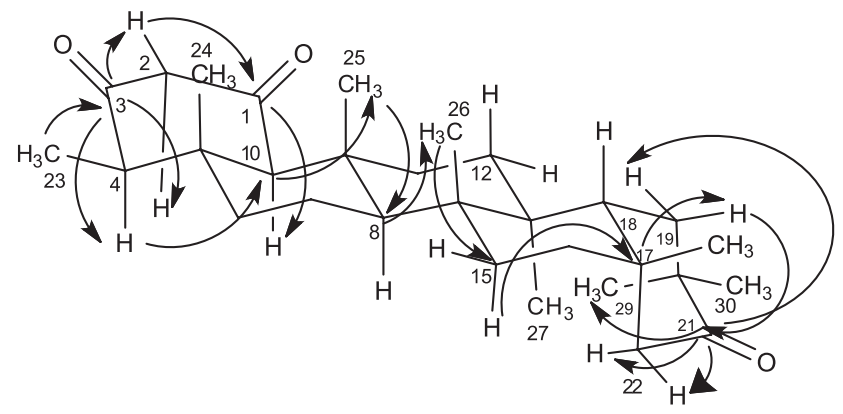

by polarization transfer (DEPT)-135, were classified as 8 primary, 9 secondary, 4 tertiary and 9 quaternary carbon atoms, suggesting a friedelane skeleton. ${ }^{20}$ Among the quaternary carbon atoms, three were characterized as carbonyl groups due to the chemical shifts at $\delta_{\mathrm{C}} 202.73$, 203.96 and 218.75. The hydroxyl groups suggested by the IR spectrum were absent in the NMR spectrum since no signals were observed for carbinolic carbon atoms. Probably, the hydroxyl bands were related to a keto-enolic equilibrium indicating triterpene $\mathbf{1}$ as a beta di-ketonic compound. In the HSQC spectrum, the signal at $\delta_{\mathrm{C}} 7.29$ (C-23) coupled with the doublet at $\delta_{\mathrm{H}} 1.05(\mathrm{H}-23)$, which is a characteristic of the friedelane carbonyl $\mathrm{C}-3$. In the HMBC spectrum, the signal of $\mathrm{H}-23$ correlated with the signal at $\delta_{\mathrm{C}} 203.96$ (C-3), which coupled with signals at $\delta_{\mathrm{H}} 2.58(\mathrm{H}-4), 3.24(\mathrm{H}-2)$ and $3.44(\mathrm{H}-2)$. Both $\mathrm{H}-2$ correlated with a second carbonyl group at $\delta_{\mathrm{C}} 202.73$ (C-1), which coupled with the signal at $\delta_{\mathrm{H}} 2.39$ (H-10). These data confirmed the positions of the carbonyl groups at C-1 $\left(\delta_{\mathrm{C}} 202.73\right)$ and $\mathrm{C}-3\left(\delta_{\mathrm{C}} 203.96\right)$, confirming a beta di-ketonic compound. The third carbonyl group was attributed to $\mathrm{C}-21$ due to the correlations between $\delta_{\mathrm{H}} 1.07$

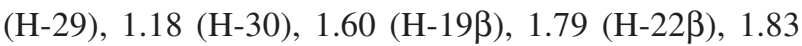
$(\mathrm{H}-19 \alpha)$ and $2.60(\mathrm{H}-22 \alpha)$ with $\delta_{\mathrm{C}} 218.78$. In the nuclear Overhauser effect spectrum (NOESY), the signal at $\delta_{\mathrm{H}} 3.44$ (H-2) was attributed to $\mathrm{H}-2 \alpha$ due to the coupling with the signals at $\delta_{\mathrm{H}} 2.58(\mathrm{H}-4)$ and $2.39(\mathrm{H}-10)$, so the signal at $\delta_{\mathrm{H}} 3.24$ was consequently attributed to $\mathrm{H}-2 \beta$. The coupling of $\delta_{\mathrm{H}} 1.05(\mathrm{H}-23)$ with $2.58(\mathrm{H}-4), 0.71(\mathrm{H}-24)$ with 1.22 (H-25), $1.22(\mathrm{H}-25) / 1.79$ (H-18) with 1.09 (H-26), and 1.79 (H-18) with 1.16 (H-28) established a chair conformation to the rings $\mathrm{B}, \mathrm{C}$ and $\mathrm{D}$. The same conformation was assigned to ring $\mathrm{E}$ because of the couplings of $\delta_{\mathrm{H}} 1.14$ $(\mathrm{H}-27) / 1.07$ (H-29) with $2.60(\mathrm{H}-22 \alpha)$, and 1.14 (H-27) with 1.07 (H-29). The most important HMBC and NOESY correlations are shown in Figure 2.

After detailed analyses of 2D experiments, compound $\mathbf{1}$ was identified as friedelan-1,3,21-trione and its complete NMR spectral data are shown in Table 1.

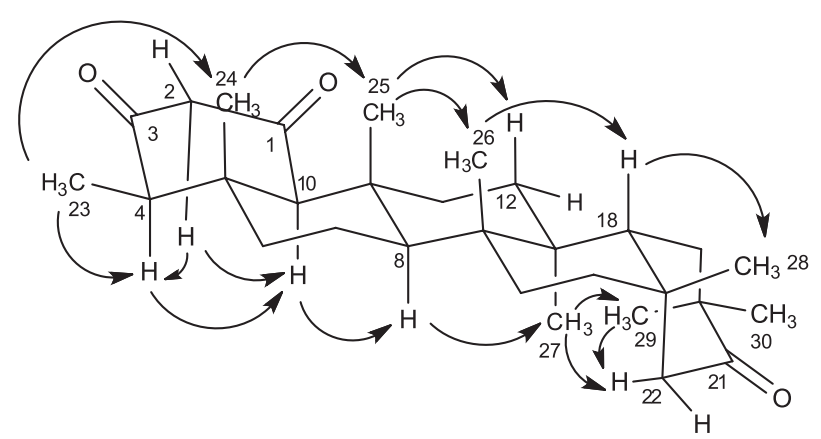

Figure 2. HMBC and NOESY correlations observed for friedelan-1,3,21-trione (1). 
Table 1. NMR spectral data of friedelan-1,3,21-trione (1) and ${ }^{13} \mathrm{C}$ NMR data of 30-hydroxyfriedelan-3-one (8) $\left(400 \mathrm{MHz}, \mathrm{CDCl}_{3}, \delta\right.$ is given in ppm)

\begin{tabular}{|c|c|c|c|c|c|c|c|c|}
\hline \multirow{2}{*}{ Position } & \multicolumn{6}{|c|}{1} & \multicolumn{2}{|c|}{8} \\
\hline & $\delta_{\mathrm{C}}$ & Type & $\delta_{\mathrm{H}}$ & $\operatorname{HMBC}(\mathrm{C} \rightarrow \mathrm{H})$ & COSY & NOESY & Type & $\delta_{\mathrm{C}}$ \\
\hline 1 & 202.73 & $\mathrm{C}$ & - & 2,10 & - & - & $\mathrm{CH}_{2}$ & 22.29 \\
\hline \multirow[t]{2}{*}{2} & 60.57 & $\mathrm{CH}_{2}$ & $3.24 \beta(\mathrm{eq})$ & - & 2 & $2 \alpha$ & $\mathrm{CH}_{2}$ & 41.52 \\
\hline & & & $3.44 \alpha(\mathrm{ax})$ & & - & $2 \beta, 4,10$ & & \\
\hline 3 & 203.96 & $\mathrm{C}$ & - & $2,4,23$ & - & - & $\mathrm{C}$ & 213.21 \\
\hline 4 & 59.04 & $\mathrm{CH}$ & $2.58 \alpha(\mathrm{ax})$ & $2,10,23,24$ & 23 & $2 \alpha, 6 \alpha, 10,23$ & $\mathrm{CH}$ & 58.24 \\
\hline 5 & 37.83 & $\mathrm{C}$ & - & $4,10,24$ & - & - & $\mathrm{C}$ & 42.15 \\
\hline \multirow[t]{2}{*}{6} & 40.52 & $\mathrm{CH}_{2}$ & $1.38 \alpha(\mathrm{ax})$ & 24 & $6 \beta$ & $4,6 \beta$ & $\mathrm{CH}_{2}$ & 41.30 \\
\hline & & & $1.89 \beta(\mathrm{eq})$ & - & $6 \alpha, 7 \beta$ & $6 \alpha, 23,24$ & & \\
\hline \multirow[t]{2}{*}{7} & 18.09 & $\mathrm{CH}_{2}$ & $1.29 \alpha(\mathrm{eq})$ & - & - & - & $\mathrm{CH}_{2}$ & 18.25 \\
\hline & & & $1.48 \beta(\mathrm{ax})$ & - & $6 \beta, 8 \beta$ & $11 \beta$ & & \\
\hline 8 & 52.40 & $\mathrm{CH}$ & $1.26 \alpha(\mathrm{ax})$ & 25,26 & $7 \beta$ & 10,27 & $\mathrm{CH}$ & 53.00 \\
\hline 9 & 37.23 & $\mathrm{C}$ & - & 25 & - & - & $\mathrm{C}$ & 37.45 \\
\hline 10 & 71.80 & $\mathrm{CH}$ & $2.39 \alpha(\operatorname{ax})$ & $2,4,6,24,25$ & - & $2 \alpha, 4,8,11 \alpha$ & $\mathrm{CH}$ & 59.51 \\
\hline \multirow[t]{2}{*}{11} & 34.48 & $\mathrm{CH}_{2}$ & $1.18 \alpha(\operatorname{ax})$ & 10,25 & $11 \beta, 12 \alpha$ & $10,11 \beta$ & $\mathrm{CH}_{2}$ & 35.58 \\
\hline & & & $2.19 \beta(\mathrm{eq})$ & - & $11 \alpha, 12 \alpha, 12 \beta$ & $7 \beta, 11 \alpha, 12 \beta$ & & \\
\hline \multirow[t]{2}{*}{12} & 30.27 & $\mathrm{CH}_{2}$ & $1.29 \alpha(\mathrm{eq})$ & 27 & $11 \beta, 11 \alpha$ & - & $\mathrm{CH}_{2}$ & 30.53 \\
\hline & & & $1.49 \beta(\mathrm{ax})$ & - & $11 \beta$ & $11 \beta, 25,26$ & & \\
\hline 13 & 39.72 & $\mathrm{C}$ & - & 26,27 & - & - & $\mathrm{C}$ & 39.81 \\
\hline 14 & 38.10 & $\mathrm{C}$ & - & 27 & - & - & $\mathrm{C}$ & 38.38 \\
\hline \multirow[t]{2}{*}{15} & 32.75 & $\mathrm{CH}_{2}$ & $1.33 \alpha(\mathrm{ax})$ & 26 & $15 \beta$ & $15 \beta, 27$ & $\mathrm{CH}_{2}$ & 32.12 \\
\hline & & & $1.55 \beta(\mathrm{eq})$ & - & $15 \alpha, 16 \beta$ & $15 \alpha, 26$ & & \\
\hline \multirow[t]{2}{*}{16} & 34.97 & $\mathrm{CH}_{2}$ & $1.38 \beta(\mathrm{ax})$ & 18,28 & $15 \beta, 16 \alpha$ & 18,28 & $\mathrm{CH}_{2}$ & 35.93 \\
\hline & & & $1.76 \alpha(\mathrm{eq})$ & - & $16 \beta$ & - & & \\
\hline 17 & 33.17 & $\mathrm{C}$ & - & $15,16,18,19,22,28$ & - & - & $\mathrm{C}$ & 30.00 \\
\hline 18 & 41.82 & $\mathrm{CH}$ & $1.79 \beta(\mathrm{ax})$ & $16,19,22,28$ & 19 & $19 \beta, 26,28$ & $\mathrm{CH}$ & 42.74 \\
\hline \multirow[t]{2}{*}{19} & 36.96 & $\mathrm{CH}_{2}$ & $1.60 \beta(\mathrm{ax})$ & 18,29 & 18 & 18,28 & $\mathrm{CH}_{2}$ & 29.34 \\
\hline & & & $1.83 \alpha(\mathrm{eq})$ & - & - & & & \\
\hline 20 & 42.75 & $\mathrm{C}$ & - & 29,30 & - & - & $\mathrm{C}$ & 33.38 \\
\hline 21 & 218.78 & $\mathrm{C}$ & - & $19,22,29,30$ & - & - & $\mathrm{CH}_{2}$ & 28.17 \\
\hline \multirow[t]{2}{*}{22} & 54.97 & $\mathrm{CH}_{2}$ & $1.79 \beta(\mathrm{eq})$ & 28 & $22 \alpha$ & $22 \alpha$ & $\mathrm{CH}_{2}$ & 38.11 \\
\hline & & & $2.60 \alpha(\mathrm{ax})$ & - & $22 \beta$ & $22 \beta, 27,29$ & & \\
\hline 23 & 7.29 & $\mathrm{CH}_{3}$ & 1.05 & 4 & 4 & $4,6 \beta, 24$ & $\mathrm{CH}_{3}$ & 6.83 \\
\hline 24 & 15.96 & $\mathrm{CH}_{3}$ & 0.71 & 4,10 & - & $6 \beta, 23,25$ & $\mathrm{CH}_{3}$ & 14.67 \\
\hline 25 & 17.79 & $\mathrm{CH}_{3}$ & 1.22 & 10 & - & $12 \beta, 24,26$ & $\mathrm{CH}_{3}$ & 18.02 \\
\hline 26 & 21.27 & $\mathrm{CH}_{3}$ & 1.09 & 15 & - & $12 \beta, 15 \beta, 18,25$ & $\mathrm{CH}_{3}$ & 19.97 \\
\hline 27 & 18.55 & $\mathrm{CH}_{3}$ & 1.14 & 18 & - & $8,15 \alpha, 22 \alpha, 29$ & $\mathrm{CH}_{3}$ & 18.59 \\
\hline 28 & 33.47 & $\mathrm{CH}_{3}$ & 1.16 & 22 & - & $16 \beta, 18,19 \beta$ & $\mathrm{CH}_{3}$ & 32.14 \\
\hline 29 & 28.78 & $\mathrm{CH}_{3}$ & 1.07 & 30 & - & $22 \alpha, 27$ & $\mathrm{CH}_{3}$ & 28.93 \\
\hline 30 & 24.97 & $\mathrm{CH}_{3}$ & 1.18 & 29 & - & - & $\mathrm{CH}_{2}$ & 71.98 \\
\hline
\end{tabular}

HMBC: heteronuclear multiple bond correlation; COSY: correlation spectroscopy; NOESY: nuclear Overhauser effect spectroscopy.

The known friedelane triterpenes $\mathbf{2}$ to $\mathbf{1 0}$ were isolated as white amorphous solid materials, pure or as mixtures. The structures of these compounds were determined comparing their respective NMR data with those previously published. Compounds 2-3 and 5-10 showed the duplet of methyl $\mathrm{H}-23$, at the range of $\delta_{\mathrm{H}} 0.8-0.9$, confirming the presence of 5 rings in the friedelane skeleton. Compound 2 was identified as friedelan-3-one and $\mathbf{3}$ as $3 \beta$-friedelinol, mainly due to the carbonyl group at $\delta_{\mathrm{C}} 213.20$ and the hydroxyl group at $\delta_{\mathrm{C}} 72.38$, respectively. ${ }^{20,21}$ The ${ }^{1} \mathrm{H}$ NMR spectrum of $\mathbf{5}$ presented seven signals of methyl groups and a singlet at $\delta_{\mathrm{H}} 3.63(2 \mathrm{H})$, relative to a hydroxylated methylene carbon. Its ${ }^{13} \mathrm{C}$ NMR spectrum showed signals at $\delta_{\mathrm{C}} 212.99(\mathrm{C}=\mathrm{O})$ and 68.08 , which were attributed to 
C-3 and C-28, respectively, characterizing the compound as 28-hydroxyfriedelan-3-one. ${ }^{20}$ Compound 6 was identified as friedelan-3-oxo-28-al due to the aldehyde signal at $\delta_{\mathrm{C}} 208.97(\mathrm{HC}=\mathrm{O})$ attributed to $\mathrm{C}-28 .^{22}$ Compound 7 showed two carbonyl groups at $\delta_{\mathrm{C}} 212.85$ and 218.74 in the ${ }^{13} \mathrm{C}$ NMR spectrum and was identified as friedelan3,21-dione. ${ }^{23}$ The ${ }^{13} \mathrm{C}$ NMR spectrum of $\mathbf{8}$ (Table 1) showed signals at $\delta_{\mathrm{C}} 213.21(\mathrm{C}=\mathrm{O}) / 71.98\left(\mathrm{CH}_{2} \mathrm{OH}\right)$ that were similar as the signals of 30-hydroxyfriedelan-3-one published by Magalhães et al. ${ }^{24}$ However, the shifts of $\mathrm{C} 12$, C16, C19, C22, C26 and C27 were uncorrectly attributed in the literature, and after a detailed analysis of the 2D NMR the assignments were corrected and are presented in Table S1 (Supplementary Information). Based mainly on the signals at $\delta_{\mathrm{C}} 213.07(\mathrm{C}=\mathrm{O})$ and $74.32(\mathrm{CHOH})$, compound 9 was identified as $21 \alpha$-hydroxyfriedelan3 -one. ${ }^{25}$ For compound 10, the signals at $\delta_{\mathrm{C}} 213.17(\mathrm{C}=\mathrm{O})$ and $75.82(\mathrm{CHOH})$ were coherent with the structure of $21 \beta$-hydroxyfriedelan-3-one. ${ }^{26}$

Compound 4 was identified as 3,4-seco-friedelan-3-oic acid due to the triplets at $\delta_{\mathrm{H}} 0.79(\mathrm{t}, J 8.43 \mathrm{~Hz}, \mathrm{H}-23)$ and $2.38(\mathrm{t}, J 8.50 \mathrm{~Hz}, \mathrm{H}-2)$ together with the signal at $\delta_{\mathrm{C}} 179.05$, which was attributed to a carboxyl group. ${ }^{27}$ The ${ }^{1} \mathrm{H}$ NMR spectrum of compound $\mathbf{1 1}$ showed an olefinic proton at $\delta_{\mathrm{H}} 5.12(\mathrm{t}, 1 \mathrm{H}, J 6.4 \mathrm{~Hz})$ and methylene groups at $\delta_{\mathrm{H}} 1.98(2 \mathrm{H}, \mathrm{m}) / 2.06(2 \mathrm{H}, \mathrm{m})$. Also, the ${ }^{13} \mathrm{C}$ NMR spectrum presented signals associated to unsaturated carbon atoms at $\delta_{\mathrm{C}} 124.25$ and 134.93 , allowing the identification of this compound as gutta-percha. ${ }^{28}$ The ${ }^{1} \mathrm{H}$ NMR spectrum of compound 12 showed signals between $\delta_{\mathrm{H}} 5.10-5.15(6 \mathrm{H}$, $\mathrm{m})$, associated to protons bonded to $\mathrm{C}=\mathrm{C}$, and between $\delta_{\mathrm{H}} 1.60-1.68$, attributed to eight methyl groups, according to integrations. Moreover, the ${ }^{13} \mathrm{C}$ NMR spectrum showed signals at $\delta_{\mathrm{C}} 124.30,124.43,131.25$ and 135.12, which were attributed to unsaturated carbon atoms, identifying compound $\mathbf{1 2}$ as squalene. ${ }^{29}$

The ${ }^{1} \mathrm{H}$ NMR spectrum of mixture 13 indicated a longchain fatty acid due to the signals of $\alpha$-carboxylic protons $\left(\delta_{\mathrm{H}} 2.34,2 \mathrm{H}, \mathrm{t}, J 7.2 \mathrm{~Hz}\right), \beta$-carboxylic protons $\left(\delta_{\mathrm{H}} 1.63\right.$, $2 \mathrm{H}, \mathrm{qt}, J 8.0 \mathrm{~Hz})$ and terminal methyl protons $\left(\delta_{\mathrm{H}} 0.88\right.$,
$3 \mathrm{H}, \mathrm{t}, J 6.4 \mathrm{~Hz}$ ). This was confirmed by the ${ }^{13} \mathrm{C} \mathrm{NMR}$ spectrum because of the signals at $\delta_{\mathrm{C}} 179.77(\mathrm{C}=\mathrm{O})$ and $14.24\left(\mathrm{CH}_{3}\right) \cdot{ }^{30} \mathrm{GC}$ analysis revealed that the mixture $\mathbf{1 3}$ was mainly composed by $66 \%$ palmitic acid, $12 \%$ stearic acid and $11 \%$ oleic acid.

\section{Antiviral activity}

The cytotoxicity to Vero cells and global antiviral activity against ZIKV of the extracts of $T$. micrantha were evaluated by the cytotoxic concentration $\left(\mathrm{CC}_{50}\right)$, effective concentration $\left(\mathrm{EC}_{50}\right)$ and selective index (SI) values presented in Table $2 . \mathrm{CC}_{50}$ values higher than $100 \mu \mathrm{g} \mathrm{mL} \mathrm{m}^{-1}$ indicate a non-toxic extract. ${ }^{31}$ On the other hand, lower values of $\mathrm{EC}_{50}$ display an effective antiviral activity. Moreover, the selective index (SI) was calculated by the ratio of the concentration of the extract that reduced cell viability to $50 \%\left(\mathrm{CC}_{50}\right)$ to the concentration needed to inhibit the cytopathic effect to $50 \%\left(\mathrm{EC}_{50}\right)$.

All leaf and branch extracts were non-toxic to Vero cells, once their values of $\mathrm{CC}_{50}$ were higher than $100 \mu \mathrm{g} \mathrm{mL}^{-1}$. The values of $\mathrm{EC}_{50}$ varied from 38.53 to $83.05 \mu \mathrm{g} \mathrm{mL}^{-1}$ indicating that the extracts presented antiviral activity. The methanolic leaf extract (MLE) together with the hexane and chloroform branch extracts (HBE and CBE) showed the highest SI displaying a promising viral inhibitory effect. All extracts with an SI higher than three were evaluated at different stages of infection (adsorption and penetration of viral particle) and also for their virucidal effect.

At the ZIKV adsorption stage, the Vero cells were pretreated with the crude extracts prior to the infection to verify interactions with cellular receptors. The ELE and MLE showed a more pronounced activity than the other extracts with a protective concentration of the cells higher than $50 \%$ at $31.2 \mu \mathrm{g} \mathrm{mL}^{-1}$ (Figure 3). These concentration values of the leaf extracts are similar to those reported by Tan et al. ${ }^{32}$ for the anti-parasitic drug suramin, which induced a ZIKV adsorption blockade of $80 \%$ at a concentration of $50.0 \mu \mathrm{g} \mathrm{mL} \mathrm{m}^{-1}$. The CBE also showed a significant antiviral activity at the concentration

Table 2. Cytotoxic concentration $\left(\mathrm{CC}_{50}\right)$ to Vero cells, effective concentration $\left(\mathrm{EC}_{50}\right)$ against ZIKV and selectivity index (SI) of the extracts of T. micrantha

\begin{tabular}{lccccc}
\hline & Extract & & $\mathrm{CC}_{50} /\left(\mu \mathrm{g} \mathrm{mL}^{-1}\right)$ & $\mathrm{EC}_{50} /\left(\mu \mathrm{g} \mathrm{mL} \mathrm{mL}^{-1}\right)$ & Selectivity index $(\mathrm{SI})$ \\
\hline \multirow{3}{*}{ Leaves } & hexane & HLE & $157.19 \pm 14.23$ & $59.09 \pm 12.46$ & 2.66 \\
& ethyl acetate & ELE & $224.96 \pm 23.78$ & $74.19 \pm 4.92$ & 3.03 \\
\hline \multirow{3}{*}{ Branches } & methanolic & MLE & $351.47 \pm 22.44$ & $83.05 \pm 12.05$ & 4.23 \\
& hexane & HBE & $181.91 \pm 12.45$ & $38.66 \pm 4.94$ & 4.70 \\
& chloroform & CBE & $370.78 \pm 43.48$ & $38.53 \pm 8.21$ & 9.60 \\
\hline
\end{tabular}


of $125.0 \mu \mathrm{g} \mathrm{mL} \mathrm{m}^{-1}$, displaying lysis plates in smaller amounts when compared to the non-treated viral control. The HBE showed no activity at this stage.

In order to evaluate the penetration stage, the Vero cells were infected with ZIKV and incubated at $4{ }^{\circ} \mathrm{C}$ for one hour. This step was necessary because lower temperatures deactivate the enzymes responsible for the viral penetration, causing only viral adsorption on the cells. Then, the extracts were added to the microplates in serial dilutions and the temperature was raised to $37^{\circ} \mathrm{C}$ to reactivate the enzymes. Both leaf extracts (ELE and MLE) protected the cell, even at the lowest concentration of $15.6 \mu \mathrm{g} \mathrm{mL}^{-1}$ (Figure 4) when compared to the viral control Ribavarin, an antiviral nucleoside analogue. The CBE partially inhibited the penetration of the virus at the concentration of $62.5 \mu \mathrm{g} \mathrm{mL}^{-1}$. The HBE promoted a partial protection of the cells only at the highest tested concentration $\left(250 \mu \mathrm{g} \mathrm{mL}^{-1}\right)$.

The ability to inhibit the viral multiplication cycle prior to the cell infection (virucidal effect) was assessed by adding serial dilutions of the extracts to the viral suspension $\left(\mathrm{moi}=0.1\right.$ virus cell $\left.^{-1}\right)$ before incubation with Vero cells. All tested extracts inhibited $100 \%$ of the viral infection even at the lowest tested concentration (15.6 $\mu \mathrm{g} \mathrm{mL}^{-1}$ ) since no virus plaques were observed in the microplates (Figure 5).

This assay demonstrated that all extracts act mainly on the viral particle. In general, an efficient antiviral agent should inhibit viral multiplication without interfering directly in the host cell, enabling a cellular infection recovery and metabolic maintenance. However, the antiviral activity was also detected for the extracts at the adsorption and penetration stage, implying the possibility of a cellular component on the mechanism as well. In fact, antiviral effects have been reported to some Celastraceae family species. Kanyara and $\mathrm{Njagi}^{33}$ demonstrated that Maytenus buchanani and $M$. senegalensis extracts were able to block HIV-10 viral infection, and Kohn et al. ${ }^{12}$ showed bovine herpesvirus inhibition by extracts of M. ilicifolia. Nonetheless, this is the first time that the antiviral potential was reported for the Tontelea genus. Further studies concerning the antiviral activity of the isolated compounds and the phytochemical investigation of more polar extracts
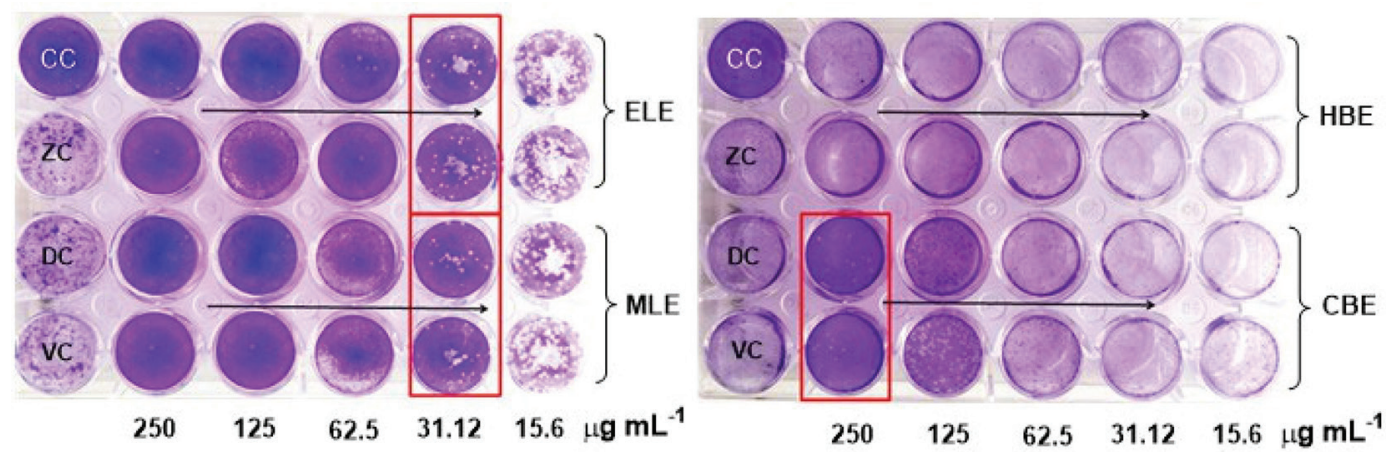

Figure 3. Effect of the extracts on cellular adsorption stage of the Zika virus. Decrease in cell damage by viral infection due to the increase in ELE, MLE, $\mathrm{HBE}$ and CBE extracts concentration. CC (cell control) = untreated and non-infected cells; VC (vehicle control) = infected cells treated with DMSO $0.2 \%$; DC $($ drug control $)=$ infected cells treated with ribavirin $\left(200 \mu \mathrm{g} \mathrm{mL}^{-1}\right)$; ZC (Zika virus control) $=$ cells infected by the virus, but non-treated. Ribavirin ${ }^{\circledR}$ was used as negative control due to its inhibition property of the viral multiplication in the intracellular phase. Tontelea micrantha samples: ELE = leaf ethyl acetate extract; MLE = leaf methanolic extract; HBE = branches hexane extract; $\mathrm{CBE}=$ branches chloroform extract.
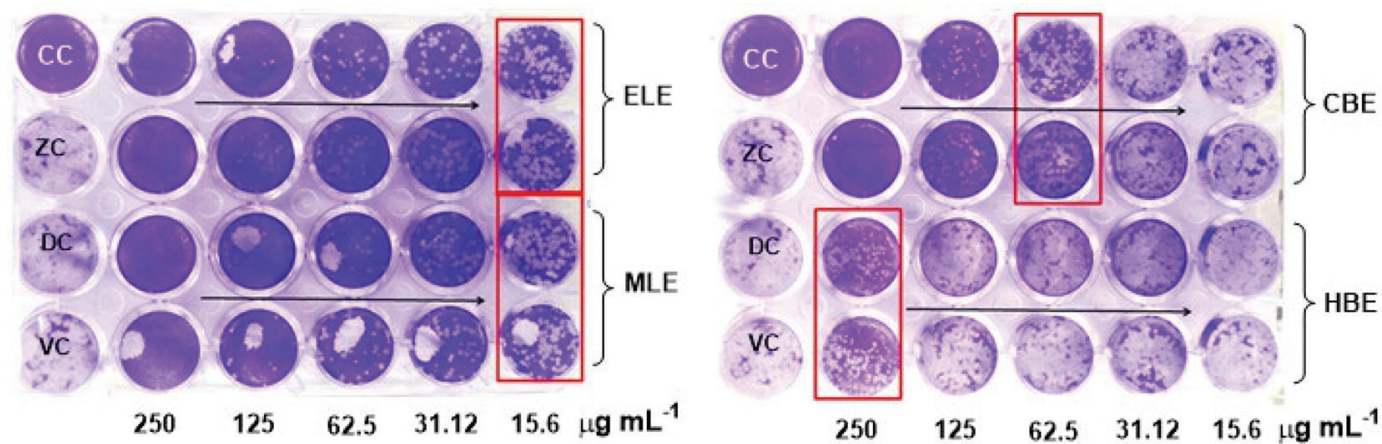

Figure 4. Effect of the extracts on the Zika virus cellular penetration stage. $\mathrm{CC}$ (cell control $)=$ untreated and non-infected cells; VC $($ vehicle control $)=$ infected cells treated with DMSO $0.2 \%$, DC $($ drug control $)=$ infected cells treated with ribavirin $\left(200 \mu \mathrm{g} \mathrm{mL}{ }^{-1}\right)$; $\mathrm{ZC}(\mathrm{Zika}$ virus control $)=$ cells infected by the virus, but non-treated. Ribavirin ${ }^{\circledR}$ was used as negative control due to its inhibition property of the viral multiplication in the intracellular phase. Tontelea micrantha samples: ELE = leaf ethyl acetate extract; MLE = leaf methanolic extract; HBE = branches hexane extract; $\mathrm{CBE}=$ branches chloroform extract. 

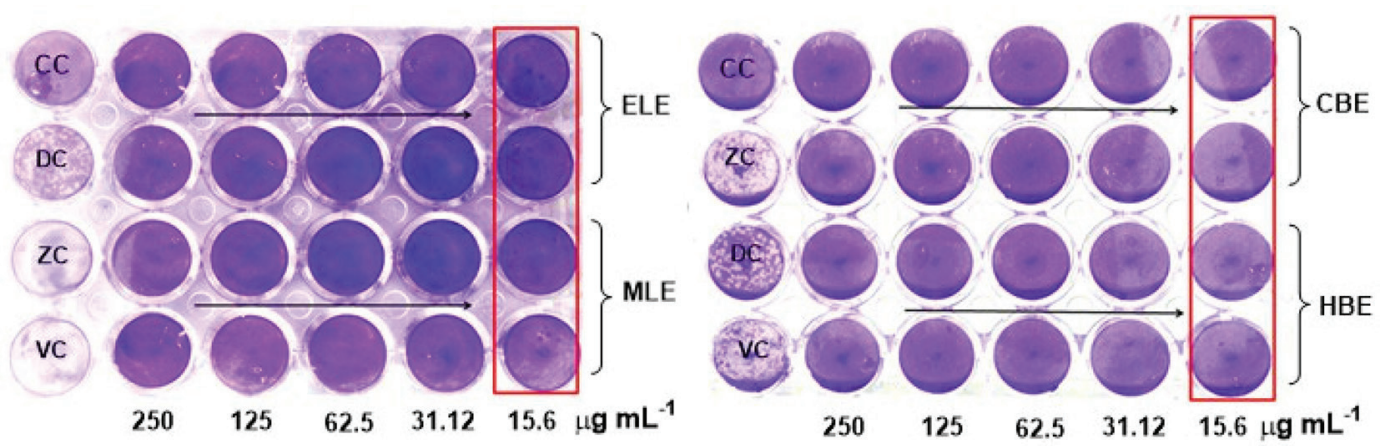

Figure 5. Virucidal effect of extracts on Zika virus particle. CC $($ cell control $)=$ untreated and non-infected cells; VC $($ vehicle control $)=$ infected cells treated with DMSO 0.2\%; DC (drug control) $=$ infected cells treated with ribavirin $\left(200 \mu \mathrm{g} \mathrm{mL}{ }^{-1}\right) ; \mathrm{ZC}$ (Zika virus control) $=$ cells infected by the virus, but non-treated. Ribavirin ${ }^{\circledast}$ was used as negative control due to its inhibition property of the viral multiplication in the intracellular phase. Tontelea micrantha samples: $\mathrm{ELE}=$ leaf ethyl acetate extract; $\mathrm{MLE}=$ leaf methanolic extract; $\mathrm{HBE}=$ branches hexane extract; $\mathrm{CBE}=$ branches chloroform extract.

are currently being performed in our laboratory, and the results will be reported in due course.

\section{Conclusions}

In this work, Tontelea micrantha was phytochemically studied for the first time. The new triterpene friedelan1,3,21-trione (1), eleven known compounds and a mixture of long-chain fatty acids were isolated and chemically characterized. This is also the first report of these compounds for the Tontelea genus. Branch and leaf extracts were also tested for their activity against ZIKV in the early stages of viral infection and virucidal effect. They presented a virucidal effect, strongly acting on the viral particle, and inhibited the infection at the adsorption and penetration stages, except for the hexane branch extract. These results demonstrate that these extracts may be promising candidates for the ZIKV treatment.

\section{Supplementary Information}

Supplementary information is available free of charge at http://jbcs.sbq.org.br as a PDF file.

\section{Acknowledgments}

The authors thank to Fundação de Amparo à Pesquisa de Minas Gerais (FAPEMIG) for the financial support and Conselho Nacional de Desenvolvimento Científico e Tecnológico (CNPQ) for the scholarships (F. L. F.). The authors also thank Salomão B. V. Rodrigues for revising the English language and critical manuscript reviews.

\section{References}

1. Núñez, M. J.; Jiménez, I. A.; Mendonza, C. R.; Chavez-Sifontes, M.; Martinez, M. L.; Ichiishi, E.; Tokuda, R.; Tokuda, H.;
Bazzocchi, I. L.; Eur. J. Med. Chem. 2016, 111, 95.

2. Veloso, C. C.; Soares, G. L.; Perez, A. C.; Rodrigues, V. G.; Silva, F. C.; Rev. Bras. Farmacogn. 2017, 27, 533.

3. Mercante-Simões, M. O.; Mazzottini, H. C. S.; Nery, L. A.; Ferreira, P. R. B.; Ribeiro, L. M.; Royo, V. A.; An. Acad. Bras. Cienc. 2014, 86, 1167.

4. Mercadante-Simões, M. O.; Paiva, E. A. S.; Plant Species Biol. 2015, 31, 117.

5. Araújo, A. R. B.; Royo, V. A.; Mercadante-Simões, M. O.; Fonseca, F. S. A.; Ferraz, V. P.; Oliveira, D. A.; Menezes, E. V.; Melo Júnior, A. F.; Brandão, M. M.; S. Afr. J. Bot. 2017, 112, 112.

6. Xiong, J.; Kashiwada, Y.; Chen, C. H.; Qian, K.; Natschke, S. L. M.; Lee, K. H.; Takaishi, Y.; Bioorg. Med. Chem. 2010, 18, 6451.

7. Qian, K.; Kuo, R. Y.; Chen, C. H.; Huang, L.; Morris-Natschke, S. L.; Lee, K. H.; J. Med. Chem. 2010, 53, 3133.

8. Silva, F. C.; Duarte, L. P.; Silva, G. D. F.; Filho, S. A. V.; Lula, I. S.; Takahashi, J. A.; Sallum, W. S. T.; J. Braz. Chem. Soc. 2011, 22, 943.

9. Niero, R.; Andrade, S. F.; Cechinel Filho, V.; Curr. Pharm. Des. 2011, 17, 1851.

10. González-Coloma, A.; López-Balboa, C.; Santana, O.; Reina, M. F.; Phytochem. Rev. 2011, 10, 245.

11. Veloso, C. C.; Rodrigues, V. G.; Azevedo, A. O. L.; Oliveira, C. C. O.; Gomides, L. F.; Duarte, L. P.; Duarte, I. D.; Klein, A.; Perez, A. C.; J. Med. Plants Res. 2014, 8, 68.

12. Kohn, L. K.; Queiroga, C. L.; Martini, M. C.; Barata, L. E.; Porto, P. S.; Souza, L.; Arns, C. W.; Pharm. Biol. 2012, 50, 1269.

13. Petersen, L. R.; Jamieson, D. J.; Powers, A. M.; Honein, M. A.; N. Engl. J. Med. 2016, 374, 1552.

14. Kindhauser, M. K.; Allen, T.; Frank, V.; Santhana, R. S.; Dye, C.; Bull. W. H. O. 2016, 94, 675.

15. Zanluca, C.; de Melo, V. C.; Mosimann, A. L.; dos Santos, G. I.; dos Santos, C. N.; Luz, K.; Mem. Inst. Oswaldo Cruz, 2015, 110, 569 . 
16. Weaver, S. C.; Reisen, W. K.; Antiviral Res. 2010, 85, 328.

17. Yasuhara-Bell, J.; Yuanan, L.; Antiviral Res. 2010, 86, 231.

18. Figueiredo, J. N.; Räz, B.; Séquin, U.; J. Nat. Prod. 1998, 61, 718.

19. Rodrigues, V. G.; Duarte, L. P.; Silva, R. R.; Silva, G. D. F.; Mercadante-Simões, M. O.; Takahashi, J. A.; Matildes, B. L. G.; Fonseca, T. H. S.; Gomes, M. A.; Vieira Filho, S. A.; Quim. Nova 2015, 38, 237.

20. Mahato, S. B.; Kundu, A. P.; Phytochemistry 1994, 37, 1517.

21. Salazar, G. C. M.; Silva, G. D. F.; Duarte, L. P.; Vieira Filho, S. A.; Lula, I. S.; Magn. Reson. Chem. 2000, 38, 977.

22. Li, Y. Z.; Li, Z. L.; Yin, S. L.; Shi, G.; Liu, M. S.; Jing, Y. K.; Hua, H. M.; Fitoterapia 2010, 81, 586.

23. Patra, A.; Mukhopadhyay, A. K.; Mitra, A. K.; Org. Magn. Reson. 1981, 17, 166.

24. Magalhães, C. G.; Ferrari, F. C.; Guimarães, D. A. S.; Silva, G. D. F.; Duarte, L. P.; Figueiredo, R. C.; Filho, S. A. V.; Rev. Bras. Farmacogn. 2011, 21, 415.

25. Setzer, W. N.; Setzer, M. C.; Peppers, R. L.; McFerrin, M. B.; Meehan, E. J.; Chen, L.; Bates, R. B.; Nakkiew, P.; Jackes, B. R.; Aust. J. Chem. 2000, 53, 809.
26. Kaweetripob, W.; Mahidol, C.; Prawat, H.; Ruchirawat, S.; Phytochemistry 2013, 96, 404.

27. Vieira-Filho, S. A.; Duarte, L. P.; Santos, M. H.; Silva, G. D. F.; Lula, I. S.; Magn. Reson. Chem. 2001, 39, 746.

28. Ferreira, F. L.; Rodrigues, V. G.; Silva, F. C.; Matildes, B. L. G.; Takahashi, J. A.; Silva; G. D. F.; Duarte, L. P.; Oliveira, D. M.; Vieira-Filho, S. A.; Rev. Bras. Farmacogn. 2017, 27, 471.

29. Barreto, M. B.; Gomes, C. L.; Freitas, J. V. B.; Pinto, F. C. L.; Silveira, E. R.; Gramosa, N. V.; Quim. Nova 2013, 36, 675.

30. Couperus, P. A.; Clague, A. D. H.; Van Dongen, J. P. C. M.; Org. Magn. Reson. 1978, 11, 590.

31. Ramos, D. F.; Leitão, G. G.; Costa, F. N.; Abreu, L.; Villarreal, J. V.; Leitão, S. G.; Said y Fernández, S. L.; Silva, P. E. A.; Rev. Bras. Cienc. Farm. 2008, 44, 669.

32. Tan, C. W.; Sam, I. C.; Chong, W. L.; Lee, V. S.; Chan, Y. F.; Antiviral Res. 2017, 143, 186.

33. Kanyara, J. N.; Njagi, E. N. M.; Phytother. Res. 2005, 19, 287.

Submitted: July 4, 2018

Published online: October 18, 2018 